\title{
A Puritan Tragedy: Reading the Stone Angel by Margaret Laurence
}

\author{
Li Yan \\ School of Foreign Languages, \\ Yan'an University \\ Yan'an, Shaanxi, China, 716000
}

\begin{abstract}
There are five parts in the article: introduction, the effects of Puritanism on the protagonist that lead to her tragedies, individual defiance, further study about the story and conclusion. The article is aimed to solve the problem of "A Puritan Tragedy" embodied in the story "the Stone Angel" by Margaret Laurence. The author's theme "A Puritan Tragedy" will be analyzed from two aspects: the effects of Puritanism on the protagonist that lead to her tragedies, and individual defiance. The present author will use such research methods as literature research method, exemlification, inductive method and analisis. Characters in The Stone Angel, will be taken as examples to illustrate the author's theme. The article is concluded that "A Puritan Tragedy" embodied in the story "the Stone Angel" by Margaret Laurence stems from the religious climates. What is new in this paper is that reasons resulting to tragedy are from Puritanism on the protagonist and her own defiance.
\end{abstract}

Keywords-Puritanism; Tragedy; Individual defiance;

Religious climates

\section{INTRODUCTION}

Margaret Laurence's life began on July 18, 1926 in the prairie town of Neepawa, Manitoba. Her father and mother were Scots and Irish descendants and were puritans. When she was very young, her mother died and her aunt, Margaret Sinmpson became her stepmother. Graduated from Winnipeg's United College in 1947, she took a job as a reporter. From 1950 until 1957 she lived in Africa, first in Somali, later in Ghana, where her husband, a civil engineer, was working. Separating from her husband in 1962, Laurence moved to England. Later she became one of Canada's most esteemed and beloved writers. She is best known for her five books about the fictional town of Manawaka: The Stone Angel, A Jest of God, The Fire-Dwellers, A Bird in the House, and The Diviners (Laurence, Angle P.1). Among them, The Stone Angel was published in England, America, and Canada in 1964. And the book alone had sold 78,000 copies in New Canadian Library edition (Thomas, World, P. 1).

The Stone Angel holds a very important place in the lineage of Canadian fiction. It tells us a story of a ninety-year-old woman, Hagar Shipley, who is grotesque with the fat ugliness of her old age. She is a proud, bitter, sick, and frightened old woman. Shackled by the rigid Puritan upbringing, her life becomes one filled with tragic events. In fact, her nature is twisted and distorted by the self-willed tragedies of her life. In her last days she recalls: "Now I am rampant with memory" (P.5). By creating the image of Hagar Shipley, a representative of early female settlers, Margaret Laurence aims to show Hagar's tragedies stem from the religious climates in which she has been raised. Margaret Laurence also aims to explore the connection between religious issues and female identity. The major focus that Laurence exhibits is conflicts between individual's needs and demands and the Puritan doctrines; and between such doctrine and man's understanding and interpretation of them.

Margaret Laurence's The Stone Angel is told through Hagar's ninety-year-old eyes, with small events triggering flashbacks that reveal her history. The novel's title is explained in the opening pages: The stone angel was a monument erected by Hagar's father for his wife, who died giving birth to Hagar. Intended to impress, the angel is doubly blind: Made of unfeeling stone, she is also eyeless, and harkens people to heaven without knowing them. As Hagar's narrative reveals, she has similar faults: Her pride and her unswerving sense of superiority often "blind" her to other people. Hagar is not apologetic about her past, but she does desire understanding.

Hagar's thoughts of the angel spark memories. As youngest child and only daughter of the town's storekeeper, Hagar is sure of her high place in the world. Her father is strict and undemonstrative, and he teaches Hagar these qualities. Inordinately proud of his position in the town, he will not jeopardize it. Laurence shows Manawaka's social hierarchy: "No-Name" Lottie Dreiser is barred from the Curries' house, and the "half-breeds" on the fringes of society are unacknowledged - although the Currie children secretly socialize with both. Hagar's fear of weakness is shown with her brother Dan's death. Matt realizes that their dying and delirious brother wants to see their mother. He asks Hagar to wear her old shawl and to comfort Dan. Hagar refuses, remembering what she has heard about her mother's meekness and frailty-qualities she detests. At age eight, Hagar has chosen her father's steeliness and determination. At eighteen, Hagar is sent to finishing school, where she learns social niceties such as embroidery, menu planning, and managing servants. Her father is pleased with her polish. Refusing 
Hagar's wish to teach, he asks her to stay in Manawaka to act as his hostess. Bitterly, Hagar does his bidding for three years. To her father's horrified disapproval, she then recklessly marries Bram Shipley and begins life on his farm. She hates Bram's shiftlessness and vulgarity.

This paper mainly analyses this Puritan tragedy from two aspects: the effects of Puritanism on the protagonist that lead to her tragedies, and individual defiance. Characters in The Stone Angel, such as Hagar, will be taken as examples to illustrate the author's theme.

\section{THE EFFECTS OF PURITANISM ON THE PROTAGONIST THAT LEAD TO HER TRAGEDIES}

Hagar's tragedies are mostly brought by her pride, and her pride can be traced to her religious family climate in which she has been raised. She grows up in a Scottish Presbyterian family. Her father, Jason Currie, is Manawaka's only merchant and a devout Puritan. He, a self-made man, always reminds his children of their noble origin, and tries to instill in Hagar the Puritan values.

When she was young, Manawaka was still close to its beginning, with a few successful business, such as, Jason Currie's store and the churches, especially the Presbyterian church: "I'd be about eight when the new Presbyterian church went up,"'( P.15)

Her father believes that God will allow people to succeed by his own labors. "He put his faith in homilies: the devil finds work for idle hands; God helps those who help themselves; many hands make light work" (P.8), hence Jason Currie's unremitting driving for success, his pride in it and its link to his religion. Hagar is deeply influenced by the Currie legacy of clan, nobility and self-made success. She does inherit from her father the stubborn character and the strong sense of pride. She fears her father but makes little effort to please him, because she doesn't want to resemble him in the least. She wants to rebel against her family but she cannot escape from its influences in the end, which are the cause of her whole life tragedy.

The name of Hagar is related to Christianity. It has its biblical origin in the Old Testament. Hagar is the Egyptian handmaid of Sarah, Abraham's wife. Sarah asks Abraham to bed Hagar so as to obtain children. Abraham does as Sarah suggests, and Hagar conceives. After her pregnancy, however, Hagar begins to despise Sarah, her mistress. In return, Sarah deals harshly with Hagar, and Hagar flees away from her face and wonders in the wilderness. Pride is the sin that has led the biblical Hagar to her torment. Hagar Shipley in The Stone Angel confronts a similar destiny. Hagar Shipley is also a wanderer through her own willfulness.

Controlled tightly by the Puritan moral principles, Hagar represses her sexual pleasure and would never admit or show her sexual pleasure to her husband, Bram. And much less does she voice her love and concern for him. But there are moments when her true feelings find their way into the open to betray her real self, as she recollects, "His banner over me was love". When she has finally left Manawaka and Bram, she often misses him terribly, although she tries hard not to admit: "I never thought of Bram in the days any more, but I'd waken sometimes, out of a half sleep and turn to him and find he wasn't beside me, and then I'd be filled with such a bitter emptiness it seemed the whole of night must be within me and not around or outside at all. There were times when I'd have returned to him just for that ..." (P.160). What she admits here shows that her sexual life is a tragedy which manifests the severe conflict between individual need and the Puritan doctrines.

\section{INDIVIDUAL DEFIANCE}

Religion has its positive and negative aspects. Believers who follow the doctrine of Christianity reconcile with their destinies and seek support and strength in God's teachings. But if one has a strong mind of one's own, yet cannot really get free from its influence, he/she will experience great pains and make a mess of his/her life.

In The Stone Angel, Hagar is the victim of her Puritan upbringing. She fails to follow the Puritan teachings about love, and the sin of the flesh, and what's more, she has too much pride. Her pride leads to all her tragedies. She is a tragic figure.

Because of her three rebellions brought by pride, Hagar goes through three tragic events in life. Firstly, Hagar, the daughter of Manawaka's only merchant and the hope of her father because of her highly intelligent mind, rebels against her stern father in order to marry Bram, a farmer who is thought common and lazy. Bram is a good-looking man, but coarse and uneducated. This fact of marriage results in the destructive relation of her and her father. Her father doesn't excuse her, so he doesn't go to see her even when she gives birth to his grandson. He lives a life alone until his death and Hagar doesn't go to her father to apologize for her deeds because of her pride. She doesn't even attend her father's burial ceremony. Secondly, after their marriage, Hagar looks down upon her husband because she feels fed up with the coarseness of him although her husband loves her. Influenced by the temperance of Puritan doctrines, she represses her sexual desire though she sometimes desires sexual life. She is so proud that she cannot endure the life with her husband in the end. Here comes her second rebellion. She escapes her husband bringing with her John, the second son, from Manawaka to the coast in order to look for a better existence. Like the first one, the second rebellion also leads to lead to family tragedy. She is thus separated from Bram for so many years, leaving him to a lonely uncared-for life. The third rebellion comes when she is a ninety-year-old woman, Hagar is then in very bad health and cannot take care of herself. She needs her son, Marvin, and her daughter-in-law, Doris's care. We are told that she "left a cigarette burning "when going to bed and "wet [her] sheets nearly every night" But due to her pride, she doesn't like her son's idea to send her to nursing home. She thus runs away from Marvin and Doris who try to help her. She makes a desperate attempt to flee to the Shadow Point, a deserted fish cannery. This rebellion puts her into a very difficult situation. On her way and during her stay there, she finds herself unable to control her body functions: for example, it is difficult for her to recover from a fall to the ground and she has forgotten to bring a single drop of water with her. This escape can be regarded as an imposed tragic dilemma. 
Later, Hagar's obstinate and interfering arrangement of John's life causes the tragedy of John's death. She places all her hopes and love on John. For example, she tells him of the once noble origin of the Currie Family because she thinks, "John was heir to the old spirit of the battle-cry."(Thomas, World P.70). She gives John the plaid of the Currie family, which is later, traded by him to another boy for a jackknife. She decides to move with John to the coast for a new life when she finds it hard for John to bear the ill reputation of Bram. John and Arlene love each other, but Hagar is not fond of Arlene and refuses to accept this girl as her future daughter-inlaw. She plans for Arlene to go the coast for separating the young couple. John, seeing his beloved leaving him, feels hopeless and cannot bear the dull environment that his mother arranges for him. So he plays the dangerous game of "crossing railroad trestle bridge by balancing on the rails". Later he and his lover drive the truck across the bridge, and end their lives. "John died, as did Arlene Simmons whom he loved; but in a stupid, pointless, drunken dare, in hopeless rebellion against a combination of Depression, poverty, and hostile circumstances that Hagar had partially contrived. (Thomas, World P.70)

Lee's family also experiences its Puritan tragedy. Murray F. Lees meets his wife, Lou, at a Bible Camp. He is fond of her and his wife is pregnant before their marriage. Under the pressure of Puritan morality, she tells others that the baby is premature, but "when Donnie was born he was nine pound twelve-what a disaster". The wife thinks that the fat baby is god's punishment to them. Lou is thus condemned because she believes in religion in a maniac manner and the great fear of the hell-fire and other punishment by God finally makes her almost insane. "All of a sudden she's a worrier, too", "but she was never the same."(P.228, 229). The real tragedy to the couple is their son's death. The child is burnt to death in a fire at home while he and his wife are at a religious service begging the God to save them when the end of the world comes.

Christianity including Puritanism has its positive and negative effects, and its negative sides often result in tragedy. Hagar's unbending pride of her spirit comes from her father and from the Bible, and it is the negative effect she has received. Her three rebellions and her arrangement of John's life, which are prompted by her pride, don't really free her, but make her suffer more. Hagar is bewildered by pride. Not until she is in her nineties does she realize that "pride was my wilderness" (P.292). She looks back on her past life and has comes to many new sights about herself and her whole life such as, she has responsibility in John's death, as well as in the destructive relation with her father and her husband. Her major mistakes come from her separating herself from others. But she realizes in the end that she has lost so much happiness, which she might have been able to enjoy if she had lived differently. In all, Hagar fails to follow the Christian Doctrine-to walk humbly before God. Her pride and also her Puritan upbringing are the origin of her tragedy.

\section{FURTHER STUDY ABOUT THE STORY}

The significance of the title of The Stone Angel by Margaret Laurence depends on the recollection by the protagonist Hagar of seeing a large marble angel in the churchyard in her hometown of Manawaka. The angel is important in many ways It is an emblem of Hagar herself, who is proud and impassive; Laurence emphasizes the parallelism when she makes Hagar think: "Is it a mausoleum, and I, the Egyptian, mummified with pillows and my own flesh, through some oversight embalmed alive? There must be some mistake. "Next, an angel is a messenger. As the stone angel is located in a cemetery, the message it bears is about death; given Hagar's age and failing health, she is both recipient of the message and also, to readers of the novel, herself a messenger, telling us the readers something about the nature of old age and death.

One of the themes in the book is the conflict and prejudice that exists between the social classes. This is highlighted by a few of the minor characters. For example, John's girlfriend Arlene is not accepted by Hagar because she believes Arlene to be beneath his social class. This fight causes the biggest rift between Hagar and her son, and John and Arlene will die in a car accident before Hagar can ever make amends.

Most of Hagar's pride and prejudice come from her father, Jason Currie. A Scottish immigrant, Jason believes in building material wealth. Although he is the descendant of a wealthy businessman, his father lost all of his money, leaving Jason a "self-made" man. He judges people as being lazy who do not have the same material status. He uses money to punish people and to glorify himself, both withholding money from his family and donating money publicly to garner himself honors.

Marvin, Hagar's son, is the character that allows Hagar to grow and change. She treats him badly throughout most of her life, claiming that he does not have the spark that she does. A quiet, hard-worker, Hagar finds him to be boring and uninspired. The final scene between them in the nursing home shows how Hagar has grown. She thanks him for how kind he always been to her, showing that she now appreciates humanity more than material wealth and showmanship.

\section{CONCLUSION}

In the article a puritan tragedy will be analyzed from two aspects: the effects of Puritanism on the protagonist that lead to her tragedies, and individual defiance. Characters in The Stone Angel, will be taken as examples to illustrate the author's theme: the tragedy stems from the religious climates. Further Study about the Story is also provided to enhance the comprehension of the story. 


\section{REFERENCES}

[1] Christl Verduyn. "Margaret Laurence An Appreciation', Journal of Canadian Studies Broadview Press, 1988.

[2] Clara Thomas. "The Manawaka World of Margaret Laurence". New Canadian Library no. 131, 1988.

[3] Margaret Atwood. "Survival". House of Anansi Press, 1972.

[4] Margaret Laurence. "The Stone Angel". The New Canadian Library, 1988.

[5] Beckman-Long, Brenda, "The Stone Angel as a Feminine Confessional Novel," in Challenging Territory: The Writing of Margaret Laurence, edited by Christian Riegel, University of Alberta Press, 1997.

[6] Frank Northen Magill."The Stone Angel - Form and Content" Masterpieces of Women's Literature Ed. eNotes.com, Inc. 1995 